\title{
Küresel Finans Kapital Çağında Devrim Arayışları: John Holloway'in Öfke Günleri Kitabı Üzerine
}

\author{
Metin Demir \\ İstanbul Şehir Üniversitesi \\ metindemir@sehir.edu.tr \\ ORCID: 0000-0002-4799-639X \\ DOI: $10.20519 /$ divan.448304
}

\section{GİRIŞ: PARA VE FELSEFE}

Felsefenin para ile ilişkisi arızi bir ilişki değildir. Daha en başında, felsefe bir bilgeliğe ulaşma tarzı olarak kendisini para ile bilgeliğin aktarılmasına karşı olarak, Sofist'e karşı olarak konumlandırdı. Her ne kadar Antik dönemde felsefe kendini paraya karşı konumlandırsa da, paranın belirleyici olmaya başladığı modern çağda felsefe ile paranın ilişkisi daha da belirgin hale gelmiştir. Adam Smith gibi politik-ekonomi filozoflarının dışında, para karşısında konumlanmak gerektiğini ilk hisseden düşünürün Kant olduğu iddia edilebilir. ${ }^{1}$ İnsanlar arasındaki toplumsal ilişkiler bütününün bir dolayım nesnesi olarak paranın kontrolü insan eyleminin kontrol altına alınmasını ifade eder. İnsani eylemin böyle bağımlılaştırılmasına karşı Kant, iradenin otonomisini öne sürer. Sadece hür iradeli olduğunun bilincinde olan insanların üyesi olduğu amaçlar krallığında eylem, fiyatı (preis) ile değil değeri (würde) ile belirlenir. Genel eşdeğer olarak para tüm metaları belirleyebilir ama iradenin otonomisine dayanan eylem koşulsuzdur; başka bir şey ile ikame edilemez, o nedenle fiyatı yoktur, ancak bir değeri vardır. $^{2}$

1 Bu iddianın derinlikli analizi için bakınız: Kojin Karatani, Transkritik: Kant ve Marx Üzerine, çev: Erkan Ünal (İstanbul: Metis Yayınları, 2008).

2 Amaçlar krallığında her şeyin ya fiyatı ( preis) ya değeri (würde) vardır. Fiyatı olanın yerine eșdeğer olarak başka bir şey konabilir, her türlü fiyatın üzerinde olan, dolayısıyla eşdeğeri olmayan değerlidir. Beceri ve çalışkanlığın piyasa fiyatı vardır; şakacı ve nüktedan olmanın, canlı bir hayal gücüne sahip olmanın duygu fiyatı vardır. Buna karşılık, ilkelerden dolayı iyi olmanın iç değeri vardır. Demek ki özerklik insanın ve her akıl sahibi varlığın değerinin temelidir (Autonomie ist also der Grund der Würde der Mensch).

\section{3}

Dîvân

$2018 / 1$ 
Kant sonrası Alman düşüncesi hep bu belirlenime karşı özgürlük fikri üzerine inşa olmuş bir ideolojidir. Bu düşüncenin en gelişmiş sistemini üreten Hegel de, insanları para üzerinden ilişkilendiren "sivil toplum"un büyük bir kitle toplumu (Pöbel) yaratacağını görerek, özgürlüğün imkanı için en yüksek ahlaklılık biçimi olarak Devlet'i önermiştir. ${ }^{3}$ Nietzsche de biriktirmeye dayalı korkarak hesap yapan burjuva karakterinin sürü ahlakına karşı eylemi, böyle hesapları aşan ve kendi değerini kendi koyan üst-insanı bir öneri olarak teklif etmiştir. Ancak parayı para olarak düşünen, kavramsal ve jeneolojik analizini en derinlikli yapan filozof muhakkak Marx'tır. Kapitalist toplumda insani somut emeğin para yoluyla dönüşerek soyut emek haline gelişini, gençlik yazılarından Kapital' e kadar giderek derinlikli bir şekilde inceleyerek, paranın kapitalist toplumsal formasyondaki kaçınılmaz yerini ve dolayısıyla öznelerin davranışlarını ve bilinçlerini nasıl belirlediğini bilimsel bir titizlikle ortaya koymuştur. 1848'de yayınlanan Komünist Manifesto'da yeni bir toplumun gelmekte olduğu idealini ilan etmiş ve sonraki 20 yılda neredeyse tüm eserlerinde para bahsine önemli bir yer ayırarak somut analizler yapmıştır.

Manifesto'nun yayınlanmasının üzerinden 170 yıl geçti, ancak paranın hükümranlığı daha da kuvvetlendi. Dolayısıyla felsefenin para ile olan ezelî savaşı hâlâ devam ediyor denebilir. Felsefe paranın hükümranlığına karşı değişik stratejilerle mücadele verdi. Alman İdealizminde gördüğümüz gibi, paranın araçsal belirleyiciliğine karşı amaç-rasyonel (Zweckrational) bir düzen ikame edilmek istendi. Ancak rasyonalite ile kapitalizmin yaptığ işbirliğine karşı Romantiklerin irrasyonalizmi ilham kaynağı oldu. Soyut ve ölü emeğin ifadesi olan para karşısında Nietzche ve Bergson'un yaşam felsefeleri, tüm mevcutların eşdeğerlik ilişkisi karşısında Varlık tecrübesinin indirgenemezliğine odaklanan Heidegger'ci eleştiriler devreye girdi.

Paranın hükümranlığına karşı önce akıl, sonra beden bir kalkan olarak düşünüldü. Ancak, kapitalist toplumsal formasyon altında para, hem rasyonel sistem hem de bedenleri örgütleyen bir sistem olarak, tüm bu eleştirilerden galip çıktı. Son yıllarda akıl-beden ikiliğinin ortasında yeni bir aktör belirdi: Duygular. Siyaseti, toplumu ve hatta ekonomiyi duygular ve duygulanımlar (affection) üzerinden düşünmek giderek daha cazip görün-

Immanuel Kant, Ahlak Metafiziğinin Temellendirilmesi, çev. İoanna Kuçuradi (Ankara: Türkiye Felsefe Kurumu Yayınları, 2009), 77-79.

3 Öte yandan, ihtiyaç, sonsuzca yeni arzular doğurduğu, sürekli olarak keyfiliğge ve dış olağanlığa tâbi bulunduğu ... sivil toplum, bu zıtlıkları ve karmaşıklıkları içinde, hem sefahat ve sefalet, hem de bu ikisi için ortak olan fizik ve moral yozlaşma manzaraları gösterir. G. W. F. Hegel, Hukuk Felsefesinin Prensipleri ya da Ana Hatlarda Doğal Hak ve Devlet Bilimi, çev. Cenap Karakaya (İstanbul: Sosyal Yayınları, 1991), 160. 
meye başladı. Felsefe sahnesinde iki aktör öne çıkıyor öyleyse: Para ve duygular.

2017 yılında yayınlanan John Holloway'in üniversite konuşmaları İletişim Yayınları tarafından yayınlandı. Bu kısa risale yukarıda bahsedildiği gibi Paranın Hükümranlığına Karşı Öfke (Rage Against the Rule of Money) alt başlığını taşıyor. Dies Irae (Öfke Günleri) adlı bir ilahiye gönderme yapan başlık, çağımızdaki dönüşümlerin getirdiği seküler gazabı öfke (duygusu değil) kavramı üzerinden ele alarak, günümüz tinini bu kavram üzerinden kavramaya çalışıyor.

Holloway'in Öfke Günleri kitabı bir tez, etrafında incelikle örgütlenmiş bir çalışma olmaktan ziyade, Leeds Üniversitesi'nde verdiği derslerin bir kaydı olması hasebiyle Rousseau'cu bir söylev niteliği taşımaktadır. Bu haliyle yanlış anlaşılmalara çok müsait olan bu kısa metnin teorik temellerini Holloway 1979 yılından beri sürdürdüğü teorik çalışmalarında atmıştır. Bu sebeple, Öfke Günleri kitabını anlamak için Holloway'in önceki teorik çalışmalarını gözden geçirmek gerekmektedir.

Holloway'in ilk dikkat çeken çalışması, 1979 yılında Sol Picciotto ile birlikte hazırladığı State and Capital: A Marxist Debate adlı derlemesidir. 70'li ve 80'li yılların Marksizmine damgasını vuran devlet tartışmasına önemli bir müdahale olarak tasarlanmış bu kitapta kapitalist birikimin süreci, kriz ve devlet biçimi tartışmaya açılmaktadır. Devlet tartışması Marksizm için iki açıdan hayati bir önem taşımaktadır. Birincisi, kapitalist üretim ilişkilerini zor yoluyla daima ayakta tutan bir destek olması bakımından kapitalist devletin analizi; ikincisi de Rus ve Çin devrimlerinde görüldüğü gibi sosyalizme geçiş süreci olarak devletin devrim açısından önemi. Bu iki bağlamda iki önemli devlet yaklaşımı şekillenmektedir: Devleti kapitalist üretim tarzının sadece bir epifenomeni olarak gören ekonomik-indirgemeci yaklaşım ve devleti özerk bir unsur olarak gören politik yaklaşım. Bu farklılaşmayı birebir takip etmese de, Marksist devlet görüşüne dair temel farklılaşma Ralph Miliband ve Nicos Poulantzas arasında cereyan eden meşhur tartışma sonucu belirginleşti. Miliband kapitalist toplumda devletin birbirinden farklı zümreler topluluğu olduğu yönündeki liberal demokratik argümana karşı geliştirdiği empirik çalışmasında, ileri kapitalist toplumlarda güçlü bir ekonomik elit grubu ve devlet elitleri grubu olduğunu, bu iki elit grubun oluşturduğu yönetici sınıfın temelde kapitalist çıkarlar konusunda anlaştığını gösterir. Ancak, bu iki grup nasıl oluyor da bir çıkar örtüşmesine sahip oluyorlar sorusu burada cevapsız kalır. Miliband sadece emprisist bir program izlediğinden sınıflar arası ilişkileri, Weberyan bir bakışla kişiler ve zümreler arası ilişkiler olarak görür ve Poulantzas onu yapısal mantığı gözden kaçırdığı için ekonomik elitler ile politik elitle- 
rin nasıl uyum içerisinde olduğunu göremediği gerekçesiyle eleştirir. Ona göre, Miliband burjuvazi ve kapitalist devlet arasındaki özel yapısal ilişkiyi gözden kaçırmakta, devletin kapitalist üretim tarzı içindeki özgün rolünü atlayarak, onu gruplar arası bir ilişkiye indirgemektedir. Devletin işleyişi ile hakim sınıfın çıkarları örtüşüyorsa bu, sistemin kendisinden dolayıdır. Onun yapısalcı perspektifinde politika, ideoloji ve ekonomi aynı bütünün farklı kerteleridir (instances). Son kertede ekonomi belirleyici olsa da, kapitalist sistemde siyasalın göreli özerkliği vardır ve ekonomik indirgemeciliğe düşmeden siyasal alan kendi kavramlarıyla (blok, hegemonya, ittifak vs.) bilimsel ve objektif olarak incelenebilir. ${ }^{4}$

Holloway, bu tartışmanın iki tarafının da temelde ekonomik olan ve politik olanın ayrılabilirliği tezine dayandığını, göreli özerklik tezinin giderek sermayenin dinamik hareketinden uzaklaşarak katılaştığını ve devleti kendisinde (in-itself) ele almaya başladığını iddia eder. Devlet biçimi, idari biçim ve Avrupa birliği gibi devlet aşırı yönetim biçimleri; sermaye birikiminin yeni formları ve varolan devlet yapısı arasındaki gerilimlerin bir sonucu olarak ele alınmalıdır. ${ }^{5}$ Holloway'e göre Miliband, Poulantzas ve Gramsci tarzı politik özerklik yaklaşımları siyasi biçimlerin gelişmesini açıklamamakta, sadece sınıflar ve hegemonya ilişkilerini açıklamaktadır. Ayrıca sermaye birikimi ile sınıf mücadelesi ilişkisi ekseninde oluşan devletin sınırlılıklarına ve dönüşümlerine odaklanmadan devleti bir gerçeklik olarak ele almaktadırlar. 70'li yılların Alman devlet türetme (Staatableitung) tartışmalarında, özellikle Joachim Hirsch'in görüşlerinden etkilenerek, devletin hakim sınıfın çıkarlarına göre yapılandığını kabul etmekle birlikte, devleti sadece hakim sınıfın bir enstrümanı olarak değil, sömürü ilişkilerinin tarihsel olarak koşullandırılmış özel bir biçimi olarak görmeyi teklif eden materyalist bir devlet teorisi önermektedir. "Devletler, sermayenin yeniden üretimi esnasında üretilen ilişkiler ve örgütsel biçimlerden ibarettir." ${ }^{6}$ Bu teoride sermaye birikimi ve devlet sınıf mücadelesi ile dolayımlanmıştır. Yani ekonomik boyut, politik boyut ile ilişki içerisinde bir birlik (totality) oluşturacak şekilde, tarihsel bir yapılaşma süreci olarak okunmalıdır. Bu tezin anlaşılması için özellikle İkinci Dünya Savaşı sonrasında devletin biçimlenmesi ve sermaye hareketi sürecini gözden geçirmek gerekir.

4Ernesto Laclau, Ralph Miliband ve Nicos Poulantzas, Kapitalist Devlet Sorunu, çev. Yasemin Berkman (İstanbul: İletişim Yayınları, 1990).

$2018 / 1$

5John Holloway ve Sol Picciotto, ed., State and Capital: A Marxist Debate (Austin: University of Texas Press, 1979).

6 Andrej Grubacic, "Neden Holloway," Kapitalizmin İçinde, Kapitalizme Karşı ve Kapitalizmin Ötesinde: San Francisco Dersleri (İstanbul: İletişim Yayınları, 2016), 9-23. 


\section{PARA VE DEVLETIN FORMASYONU}

Bilindiği gibi 1929 Büyük Buhranı Amerika Birleşik Devletleri'nin (ABD) uzun süreli büyümesi sonucu ortaya çıktı. 1920'lerde tarıma talep azalmış, fiyatlar düşmüş, makineleşme ile birlikte verimlilik artışı sermayeyi büyütmüş, ancak ücretlerde düşüşe neden olmuştu. Biriken sermaye spekülatif alanlara kaymış, aşırı değerlenen hisse senetleri 1929'da New York borsasında ani çöküşe neden olmuş, Avrupa'ya verilen kredilerin uzatılmaması krizin Kıta Avrupasına taşınmasına neden olmuştu. Bu koşullarda kurtarıcı olarak beliren Keynesçi politika, sermayenin ihtiyaç duyduğu talebin, borçlanmayı göze alan (deficit spending) devlet tarafından yaratılabileceğini öngörüyordu. 1933'te Roosevelt döneminde devreye giren New Deal politikaları ile birlikte devlet; istihdam yaratan kamu kuruluşları, işçilerin sendikalarda birleştirilmesi, gelir dağılımına müdahale, hükümet destekli korporatizm ile emek ve sermaye arasında yeni bir işbirliği sağlayacaktı. Kitle imha silahları üretimiyle savaş korporatizmi, telekominikasyon sektörü ile devlet-sermaye işbirliği, sendikalar yoluyla sermaye-emek korporatizmi sağlanmış oldu. Kapitalizmin altın dönemi olarak görülen Keynesyen refah devleti ile laizes-faire ekonomisinin sonu gelmiş, artık para sadece uluslararası değişim aracı değil, aynı zamanda ulusal yönetim enstrümanına dönüşmüştü. ${ }^{7}$ Faşizm dönemi ve kapitalist demokrasilerde ekonomik işlevi artmış devlet; yatırım yapmak ve kamusal altyapı çalışmalarını yürütmek, talep yaratmak, gelir dağılımına müdahale etmek, kamu iktisadi teşekkülleri oluşturmakla sermayenin önemli bir parçası haline gelmişti. ${ }^{8}$ Savaş sonrası dönemde 70'li yıllara kadar devlet ve şirketlerin aldığı kredilerle tam istihdam ve yüksek kârlılık oranları yakalanıyor, edinilen kâr ile faizler ödeniyor ve devlet harcamaları artıyordu. Önce kredi sonra yüksek istihdam ve ücretle kışkırtılan talep sermaye yoğunlaşmasını mümkün kılıyordu. 1944 yılında Bretton Woods anlaşması ile dünya çapında para akışını sağlayan ve yöneten iki örgüt inşa edildi: IMF (International Monetary Fund) ve Dünya Bankası. Altın rezervi ile güvence altına alınan $\mathrm{ABD}$ doları (35 dolar = 1 ons altın) dünya pazarı için küresel rezerv para olarak kabul edildi. Sabit kur sistemi altında malların serbest ticareti teşvik edildi. 1947'de ABD savaştan zarar gören, sonradan adı OECD (The Organisation for Economic Co-operation and Development) olacak ülkelere Marshall planı uyarınca krediler vererek onlara Amerikan malları satarak bu ülkelerin kalkınmasını ve dünya pazarının dolar üzerinden oluşumunu sağladı.

7 Georg Fülberth, Kapitalizmin Kısa Tarihi, çev. Sadık Usta (İstanbul: Yordam Yayınları, 2010), 212.

8 Fülberth, Kapitalizmin Kısa Tarihi, 224 
1944-1970 arası dönemde neredeyse tam istihdam sağlanmış, ücretler yükselmiş, görülmemiş boyutlara ulaşan işçi nufüsun devletin sağladığı sosyal imkanlarla (eğitim, konut, sağlık, emeklilik, altyapı vs.) refaha kavuşmasıyla adeta eşitlenmiş bir ortasınıf toplumu yaratılmıştı. Ücret artışı ve sendika baskasının yarattığı enflasyon tehdidine, devalüe edilmiş ABD dolarının Avrupa'ya yağmur gibi yağması eklendi. ${ }^{9}$ Vietnam savaşını para basarak finanse eden $\mathrm{ABD}$, kendi altın rezervlerinde karşıllı̆ını gösteremeyeceği miktarda doları piyasaya sürünce 1971'de Nixon döneminde sabit kur sistemi terk edildi.

Ücretlerin yüksek olması, sendikaların baskı yapması, vergilerin yüksekliği ve sürekli artan kamu masrafları sermayede durgunlaşmaya yol açtı. Bu aşamada ilk defa 1947 'de İsviçre toplanan Mont Pelerin Cemiyeti'nin neoliberal yaklaşımı dikkat çekmeye başladı. Aralarında Ludwig von Misses ve Milton Friedman gibi iktisatçılar, Friedrick von Hayek ve Karl Popper gibi filozofların bulunduğu bu grubun temel iddiası refah devleti düzeninde insan serbestiyetinin tehlikeye girdiği; bunun ancak devletin çekilmesi ve özel teşebbüsün öne çıkması ile çözülebileceğiydi. Keynesyen talep denetimi yoluyla enflasyona müdahale yerine, arzı artırarak enflasyonla mücadele ve fiyatlarda ucuzlama öngören arz yönelimli monetarist yaklaşım Friedman tarafından teklif edildi. Robert Lucas'ın rasyonel beklentiler, Buchanan ve Tullock'ın kamu tercihi (public choice), nihayet Arthur Laffer'in vergi oranlarının düşürülmesinin devlet gelirini artıracağı tezleri, hükümet müdahalesinin çözüm değil sorunun kendisi olduğunu, istikrarlı bir para politikası ile beraber üst gelir dilimleri için vergi indirimlerinin daha sağlıklı bir ekonomi üreteceğini savunmaktadır. ${ }^{10}$ Bu tezleri savunanlara göre arz yönelimli ekonominin canlanması için; vergiler düşürülmeli, kamu iktisadi teşebbüsleri özelleştirilmeli, üretimi kısıtlayan denetleyici faktörler hafifletilmeli, yabancı sermaye akışı ile girişimci desteklenerek iyi bir iş iklimi yaratılmalıydı.

İlk defa 1973'te sosyalist Allende'nin darbe ile devrilmesinden sonra Şili'de uygulanan neoliberal politikalar, daha sonra 70'lerin sonralarında ABD'de Reagon ve İngiltere'de Thatcher ile devreye sokuldu. ABD merkez bankası başkanı Paul Volcker, 1979'da özel şirketlerden alınan vergiyi \%70'den \%28'e indirerek tarihin en büyük vergi indirimine imzasını attı. Ortadoğudan gelen petro-dolarlar ile zenginleşen ABD fonları, gelişmekte olan ülkelere ABD bankaları lehine faiz oranları ile borç vererek, onları ağır borçlar altına girmeye teşvik etti. Ülkeler borcun ertelenmesine karşıllk

9 Fülberth, Kapitalizmin Kisa Tarihi, 246.

10David Harvey, Neoliberalizmin Kısa Tarihi, çev. Aylin Onacak (İstanbul: Sel Yayıncılık, 2015), 62. 
özelleştirme, emek piyasasının esnetilmesi, deregülasyonlar, sosyal refahın kısıtlanması gibi yapısal uyum reformları yapmak zorunda kaldılar ve uluslararası finans sistemine bağımlı hale geldiler. ${ }^{11}$ Birçok ülkede Warren Buffet, Richard Branson, George Soros, Carlos Slimm gibi girişimciler ortaya çıktı. Bilgi teknolojilerindeki gelişmeler sayesinde üretim ekonomisinin yerini finans ekonomisi aldı ve kredilerin ve borçlanmanın önü sonuna kadar açıldı. Bunun sonucunda 1994'te Meksika, 1997'de Güneydoğu Asya, 1998'de Rusya, 1999'da Brezilya, 2001'de Türkiye, 2002'de Arjantin borçlarını ödeyemeyerek finans krizine girdiler. ${ }^{12}$ Batan ülkere kurtarma paketleri ile yeni borçlar verilerek daha da bağımlı hale getirildi. Sıkı para politikasına geçilmesi, şirket ve özel mülkiyet vergilerinin düşürülmesi, kamu iktisadi teşekküllerinin özelleştirilmesi, sosyal giderlerin özel sektöre devredilmesi, sermaye hareketinin önüne geçen (vergi, planlama, denetim gibi) engellerin kaldırılmasını içeren paketleri sunuldu. İyi bir iş iklimi için finans kurumlarının genişletilmesi ve desteklenmesi önerildi, ancak finans kurumları hata yapıp batınca, monetarist politika gereği, paranın istikrarını korumak adına bankaların mali temerrüdüne devlet müdahalesi ile müsade edilmedi. ${ }^{13}$

Neoliberal yaklaşımda ilkece devlet serbest piyasaya karışmaması gerekirken, devletin müdahalesi sadece banka kurtarmak ile kalmaz. Devlet özelleştirme yoluyla mülksüzleştirme, (tarım, turizm, doğal kaynaklar üzerinde müdahale ile) özelleştirme, bankaları destek ile finansallaşmayı destekleme, kriz ve müdahalelerle yeniden sermaye dağıtımında aktif rol oynamaktadır. Yani Keynesçi refah devleti sonrasında devlet piyasadan çekilmemiş, çoğu zaman sermayenin yanında ve sıklıkla baskıcı bir şekilde sermaye ile işbirliği yapmıştır. Demokratik ve parlamenter karar alma süreçlerinden ziyade, neoliberal yönetimler uzman ve seçkinlerin oluşturduğu bir oligarşiyi destekler, kararnameler ve yargı kararlarıyla yönetimde güçlü olmayı tercih ederler. Polanyi'nin Büyük Dönüşüm'de belirttiği gibi liberal ütopyacı proje nihayetinde otoriterliğe başvurularak sürdürülebilir. ${ }^{14}$ Devlet piyasa şartlarının işlemesi için gerekli düzen adına sürekli devreye girer, stratejik hedefleri haklara tercih eder. Klasik liberal görüşün önerdiği piyasanın bekçiliği rolünün çok ötesine geçen "devlete düşen misyon 'kurucu' ilke olarak rekabetten yola çıkarak, 'genel çerçevenin son gözetmeni olmak' bütün iktasadi faaliyetlerin buna saygı göstermesine göz kulak olmak ve 'düzen-çerçeve'yi yerli yerine oturtmaktır. Liberal döne-

11 Harvey, Neoliberalizmin Kisa Tarihi, 35

12Fülberth, Kapitalizmin Kısa Tarihi, 275.

13 Harvey, Neoliberalizmin Kisa Tarihi, 81.

14Harvey, Neoliberalizmin Kısa Tarihi, 78.

Dîvân

$2018 / 1$ 
min piyasa şartlarını idame etmekle görevli devleti, neoliberal dönemde kendisini de piyasa şartlarında bir şirket gibi görmeye başlamıştır." ${ }^{15}$

Görüldüğü gibi büyük buhrandan günümüze devlet ile sermaye arasındaki ilişki farklı formlar alarak sürekli sürmüş, devlet emeği kontrol vesilesi olarak sermaye ile emek arasında aracı rol üstlenmiştir.

\section{HOLLOWAY'A GÖRE PARA VE DEVLET}

State and Capital: A Marxist Debate adlı çalışmanın bir devamı niteliğinde olan 1991 yllında yayınlanan Post-Fordism and Social Form: A Marksist Debate on Post-Fordist State ${ }^{16}$ isimli makaleler derlemesi olan çalışmada John Holloway ve diğerleri kapitalist üretim ilişkilerinde gerçekleşen dönüşümlerin yarattığı yeni tahakküm biçimlerinin devleti nasıl dönüştürdüğünü tarihsel bir akışla göstermekte. Bu çalışmada bir önceki eserde teorik çerçevesi ortaya konulan, ekonomik olan ile politik olanın nasıl iç içe geçtiğini, sermaye birikimindeki artışının nasıl zorunlu olarak emek üzerinde tahakküm artışını getirdiğini ve devletin de bu mücadele ekseninde nasıl dönüştüğünü ortaya koymaya çalışırlar.

Post-Fordizm üzerine analizlerini 1995 yllındaki Global Capital, National State, and the Politics of Money kitabiyla yeniden şekillendiren Holloway, neoliberal dönemde sermayenin sanayiden kaçışı ile üretici sermayenin finansal/parasal sermayeye dönüşümünün yarattığı değişimleri inceler. Daha 1986 'da finansal işlemler dünyadaki reel ticaret hacmini 25 kat aşmış (bugün 100 kat aşmış durumda) iken bu yeni koşullarda sermaye, sınıf mücadelesi ve devlet arasındaki ilişkiyi nasıl ele alacağımızı tartışır.

Krizdeki kapitalizm için itaatsiz emeği sermaye ilişkilerine tâbi kılma girişimi olarak Keynesçi refah devletinin krizini ve parasalcılığın yükselişini anlatan Holloway, 90'lı yıllarla birlikte gelen kredi genişlemesi ve borç krizi dolayısıyla yeni egemenlik biçimlerini tartışmaya açar. Brezilya, Arjantin, Türkiye, Meksika gibi ülkelerde borç krizi, ödeme dayatmaları ve kemer sıkma politikalarını, daha önce refah devletinin uhdesinde olan sağlık, barınma, eğitim, ulaşım gibi tüm alanların piyasaya tahvil edilmesini göz önüne aldığımızda vatandaşların paranın ve kredinin iktidarına salıve-

Dîvân

$2018 / 1$

15Pierre Dardor ve Christian Laval, Dünyanin Yeni Akll: Neoliberal Toplum Üzerine Deneme, çev: Iş̧1 Ergüden (İstanbul: İstanbul Bilgi Üniversitesi, 2012), 410.

16 Post-Fordism and Social Form: A Marksist Debate on Post-Fordist State, ed. Werner Bonefeld ve John Holloway (London: Macmillan, 1991). 
rilmesini görebiliriz. Öyleyse devleti izole bir özerk siyasal birim olarak düşünmek yerine, sınır tanımayan finansal sermaye ile dinamik bir ilişki içinde idrak etmemiz gerekir. 80'li ylllarda mevcut sömürünün yetersizliği, meta piyasasının doygunluğu, kârlılığın düşüşü; sermayeyi fabrikadan ve ulus devletten kaçmaya ve daha mobil olacağı finans ve kredi alanına kaçmaya itmiştir. Fabrikadan, betondan, üretimden kaçan sermayeyi tekrar kendine çekmek, onu tekrar sabitlemek için tüm devletler yönetsel değişikliklere gitmek zorunda kalmışlardır. "Sermayenin en genel ve en soyut biçimi olan para dolayımıyla sermaye küreseldir, akışkandır ve serbestçe dolaşabilmektedir... Egemenlik paraya geçmiştir ve devlet 'kapitalist toplumun antagonist ve kriz eğilimli gelişiminin bir parçası' olarak görülmesi gerekir" diye düşünür Holloway. ${ }^{17}$ Ancak bu, paranın sadece ekonomik bir kategori olmadığını, aynı zamanda politik bir kategori olduğunu ve antagonistik sınıf ilişkileri bağlamında anlaşılması gereken bir şey olduğu manasına gelir. ${ }^{18}$ Holloway paranın hükümranlığında, diyalektik olarak onun zayıflığını ve kriz ihtimalini de görmektedir. Zira, ona göre kredi genişlemesi sermayenin emeği itaatkar kılmada güçsüzleștiğinin göstergesidir.

Görüldüğü gibi Holloway devlet tartışmasının, küresel sermaye ilişkileri bağlamında ve bu ilişkilerin özünde bulunan sınıf mücadelesi ekseninde Marksist bir okumasını yapar. Yazarın daha çok tanınmasının sebebi Açık Marksizm adıyla anılan bir projenin önemli aktörlerinden biri olmasıdır. 1995'de yayınlanan üç ciltlik Open Marxism ${ }^{19}$ adlı çalışmada, ortodoks Marksizmin yerleşik kavramlarını çağdaş dünyanın değişikliklerine açmak, dolayısıyla Marksizmi tartışmaya açmak hedeflenmektedir. Marx’ı özgürleştirmek adını verdikleri girişim öncelikle bilimsel Marksizmin ekonomizmini aşarak ekonomi, politika ve özgürleşmeyi yeniden ilişkiye sokmayı hedeflemektedir. Özgürleşmekten ikinci kasıt ise, Marksizmi bir devrim projesi olarak, bir özgürleşme çabası olarak yeniden yorumlamaktır. Onlara göre Marksizm dünyaya her koşulda aynen uygulanması gereken değer-bağımsız, objektif, katı bir bilimsel çalışma değil, teorinin pratik mücadele içinden çıktığı bir teori-pratik birliğidir. Ancak, klasik Marksizm bu dinamizmi unutarak teoriyi fetişleştirmekte, onu kendi başına bir varlık olarak ele almaktadır. Bu zihniyet giderek Marksizmin özünde yer alan dünyayı değiştirme fikrinin kaybolmasına yol açmaktadır. Bu problemleri aşmak için Marksist özgürleşme (emancipation) kavramına başvurmakta,

17 Küreselleşme Çağında Para ve Sinıf Mücadelesi, ed. Werner Bonefeld \& John Holloway, çev: Serkan Mercan, (İstanbul: Otonom Yayıncılık, 2007).

18 Global Capital, National State, and the Politics of Money, ed. Werner Bonefeld \& John Holloway, Palgrave Macmillan, 1995.

19 Open Marxism vol III: Emancipating Marx, ed. Werner Bonefeld, Richard Gunn, John Holloway ve Kosmas Psychopedis (Pluto Press, 1995). 
teoriyi tecrübe ile ilişkiye sokarak dinamizm sağlamaya yönelmektedir. Daha önceki çalışmaları ile paralellik arz edecek şekilde, Marksist teoriyi güncel değişimlerle dinamik ilişkiye sokarak okumaya çalışmaktadır. Sabit kavramları dönüştürüp yeniden yorumlayarak ve her şeyi sınıf mücadelesi ekseninde algılayarak düşünmek Holloway ile açık Marksizm projesinin ortak özellikleridir.

\section{DEVLET VE DEVRIMDEN, DEVLETSIZZ DEVRIME}

Marksizmde yeni arayışlar fikri Holloway'i Marksist devlet tartışmasından devlet olmadan devrim fikrine yöneltmiştir. Onun 2002'de yayınlanan Change the World Without Taking Power ${ }^{20}$ adlı kitabı birçok tartışmaya yol açmıştır. Bu kitapta yazar, önceki eserlerinden belirgin bir farklılık göstererek, sermaye hareketinin yarattığı dönüşümlerin Marksist bir analizini yapmaktan ziyade, devrimi merkeze alarak sermayeyi ikinci plana çeken daha anarşist bir ton kullanır.

Düşünce hareketinin merkezine sınıf mücadelesini yerleştiren Holloway, bu sebeple çalışmasında ezilenlerin bakış açısını temel alır ve "çığlık" (scream) kavramı ile başlar. Ona göre "çığlık, kusurlu bir dünyanın reddi, bizim aleyhimize işleyen dünyaya Hayır! diyen bir sestir." ${ }^{21}$ Burada dikkat çekici husus projenin, anlamı olan bir sözden (logocentric), yani bir öneriden değil, bir çığlıktan başlamasıdır. Peki, bizim aleyhimize olan dünyaya hayır diyen bizler kimiz? "Elbette ki bu 'biz' saf, yüce bir Özne değil, Bizler Erkekler ya da Kadınlar ya da İşçi Sınıfı değiliz, hiç değilse şu ana dek. Tüm bunlar için fazlasıyla karmaşığız.”22 Görüldüğü gibi Holloway, düşüncesinin merkezine sermayeye karşı sınıf mücadelesini yerleştirirken, sınıfın anlamını oldukça genişleterek sermayenin tahakkümünden muzdarip olan herkesi -sanatçıları, köylüleri, eğitimcileri, işçileri, gençleri- içine alacak şekilde genişletir. Sınıf kimliğini kendi içine kapanan ve sözsel olarak tanımlanabilen bir özdeşliğe indirgememeye gayret eder. Feryat eden "biz" sermaye karşısında güçsüzleşen, memnuniyetsiz büyük kitlelerdir. Peki bu kitleler gücü tekrar nasıl ele geçirecekler? Bu sorunun tarihsel cevapları geçtiğimiz yüzyılda tanıklık ettiğimiz parti kurma, halk ayaklanması, gerilla savaşı, ulusal kurtuluş mücadelesi, sosyal demokrat parlamenter mücade-

20 John Holloway, Change the World without Taking Power (London: Pluto Press, 2002).

21 John Holloway, İktidar Olmadan Dünyayı Değiștirmek, çev. Pelin Siral (İstanbul: İletişim Yayınları, 2015), 13.

22Holloway, İktidar Olmadan Dünyayı Değiștirmek, 16. 
le gibi alternatifler olabilir. Holloway'in radikal iddiası; sermaye karşısında gücü ele geçirmenin tek yönteminin dünyayı iktidar olmaya talip olmadan değiştirme arzusunda israr etmektir.

Leninist devrimci parti projesi ve sosyal demokrat reform projesinin (Kautsky ve Bernstein) her ikisi de temelde devlet aygıtının gücünü kabul eder ve değişimi ancak devleti ele geçirmekle mümkün görür. Devrimci ve reformist alternatiflere karşı daha anarşist bir pozisyonda duran Holloway açıkça, "İktidarın kendisi bir kez mücadelenin içine sızdığında, iktidarın mantığı devrimci sürecin mantığı haline geldiğinde, isyanın negatifliği iktidar-yapıcılığın pozitifliğine dönüştüğünde mücadele kaybedilmiştir." der. ${ }^{23}$ Önce iktidarı ele geçirme sonra da daha iyi bir dünya yaratma projesinin devrim değil, iktidar mantığı üreteceğini iddia eder. Leninist projenin karşısına Meksika'daki Zapatista mücadelesini esas alan yazar, devrimci mücadelenin devleti ele geçirerek değil, devletin hiyerarşik iktidar mantığına karşı gelerek sürdürülebileceğini düşünür. Aynı zamanda Açık Marksizm projesi uyarınca, devrimci mücadelenin fetişleşmiş, katı bir teorik çerçeveyi deneyime uygulama hatasına karşı, Marx'ın Feuerbach Üzerine Tezler'de yaptığı gibi, pratik ve teorinin birliğini savunarak, teorinin dünyayı değiştirme mücadelesinin bir parçası olması gerektiğini hatırlatır. ${ }^{24}$

Esasında, kitabın temel tezi, yapma gücü (power to-, potentia) ile yaptırma gücü (power over, potestas) arasındaki kavramsal ayrım üzerine bina edilir. Halloway'e göre, iktidar tam da yapma gücünün yaptırma gücüne; diğerlerinin yapma güçleri üzerinde bir baskıya dönüştüğü anda başlar. Dolayısıyla sömürünün başladığı yerde yapabilme gücü olan eyleyiş, bir başka amacın egemenliği altına girerek soyut emeğe, yani yaptırma gücüne dönüşür. Böylelikle aktiflik pasifliğe, öznellik nesnelliğe, yapma yeteneği yeteneksizliğe dönüşür. ${ }^{25}$ Tam bu noktada Marksist yabancılaşma tartışması gündeme gelir. Marx'ın 1844 El Yazmaları'nda söylediği gibi

\section{Holloway, İktidar Olmadan Dünyayı Değiştirmek, 33.}

24Böylece Hristiyanlığın Özü'nde teorik tutumu, biricik gerçek insan tutumu olarak görüyor, oysa pratik yalnızca iğrenç, Yahudice görünüm biçimi içersinde kavranıyor ve sabitleştiriliyor. Böylece "devrimci" faaliyetin, "pratikeleştirel" faaliyetin önemini anlamıyor... Nesnel [gegenständliche] hakikatin insan düşüncesine atfedilip atfedilmeyeceği sorunu -bir teori sorunu değil, pratik bir sorundur. İnsan; hakikati, yani düşüncesinin gerçekliğini ve gücünü, bu dünyaya aitliğini [Disseitigkeit] pratikte kanıtlamalıdır. Pratikten yalıtılmış düşüncenin gerçekliği ya da gerçeksizliği konusundaki tartışma, tamamıla skolastik bir sorundur. Karl Marks-Frederich Engels, Alman İdeolojisi (Feuerbach), çev. Sevim Belli (Ankara: Sol Yayınları, 1976), 9-10.

25John Holloway, İktidar Olmadan Dünyayı Değiştirmek, çev. Pelin Siral, (Ankara: İletişim Yayıncılık, 4. Bsk, 2015) 49. 
"sermayenin özü, eyleyişin somut emeğe dönüşmesi, işçinin canlı emeğinin karşısına yabancı bir güç olarak çıkmasıdır." ${ }^{26}$ Yani kapitalist üretim tarzında eyleyiş eyleyenden koparılır, karşısına yabancı bir nesne olarak metalar, değer ve sermaye biçiminde fetişleşmiş bir şekilde çıkar.

Zaten Holloway'e göre "fetişizm Marx'ın iktidar tartışmasının çekirdeği ve dünyayı değiştirmeye dair bütün tartışmalarının merkezidir." ${ }^{27}$ Kapital'de incelendiği şekliyle meta fetişizmin insanların arasındaki ilişkilerin şeyler arası ilişkiler halinde görülmesidir. Para ve emek-değer, insanlar arası ilişkinin bir ürünü iken sanki şeylerin bir özelliği imiş gibi görünerek fetişistik bir karakter kazanır. Öyleyse, fetişizm insani etkinliğin unutulması, şeyleşerek donmasıdır. Bu konuda şeyleşme (Lukacs), araçsal akıl (Horkheimer), özdeşlik (Adorno), disiplin (Foucault) gibi kavramlarla insanlar arasındaki ilişkilerin nesneleşerek tahakküm aracına dönüşmelerini inceleyen eleştirel teori geleneğine katılan Holloway, iktidarı tam da insanlar arası ilişkileri şeyleştiren bir dönüştürücü olarak algılar. Yaptırma gücüne dayanan iktidar mantığının somutlaşmış halleri olan sermaye, devlet, parti, sınıf gibi kavramlar tam da eyleyişin katı bir disiplin içinde sınırlandırıldığı yapılar olduğundan, Marksist yabancılaşmaya karşı özgürleşme projesi bunların tümüne karşı “Hayır!” çığlığını kuşanmaktan geçer. "Çığlığın mücadelesi yapma-gücünü iktidardan, eyleyişi işten, özneliği nesneleşmekten kurtarma mücadelesidir.... Yaptırma gücü (iktidar) namlunun ucunda olabilir ${ }^{28}$ ancak yapma gücü olamaz. ...İktidar olmaya odaklanan devrim anlayışları tipik bir biçimde karşıt güç fikri etrafında toplanır." ${ }^{29}$ Demek ki devrimci mücadele "yaptırma gücünün yok edilmesi yapma gücünün özgürleşmesi” için verilecek mücadele olmalıdır. Böyle kavranılan bir mücadele anlayışına göre bilimsel Marksizm eleştirelliği ve mücadeleyi unutturan, ${ }^{30}$ deneyimin ızdırabını tarihsel determinist şemalara ya da ekonomik belirlenimci bir araçsallığa bırakan, kısaca özgürleşmenin önünde engel olan fetişleştiricilerdir. "Nesnel koşullar diye bir şey yok: Bizler, sadece ve sadece bizler kapitalizmin çelişkisiyiz. Tarih kapitalizmin gelişim yasalarının tarihi değil, sınıf mücadelelerinin tarihidir.” (yani sınıf-

$26 \mathrm{Bu}$ olgu göstermektedir ki emeğin ürettiği nesne -emeğin ürünü- emeğin karşısına yabancı bir şey, kendini üretenden bağımsız bir güç olarak dikilir. Emeğin ürünü; bir nesneye aktarılmıș, maddeleșmiș emektir: Emeğin nesneleștirilmesidir. Nesnenin yok oluşu ve nesneye kölelik, mülk sahibi ise yabancılaşma, başkalaşma olarak ortaya çıkar. Karl Marx, 1844 El Yazmalarl, 10. bas., çev. Murat Belge (Birikim Yayınları, 2016). 
landırma ve sınıflandırmaya karşı gelme mücadelelerinin) diyen Holloway görüldüğü gibi nesnel analiz yapan bilimsel Marksizm yerine yukarıda belirttiğimiz gibi mücadeleyi koyar, devrim özne olarak işçi sınıfının yerine feryat eden madunları koyar. Böylece artık Marksist "teori... eyleyişi geri kazanmak için eleştirellik doğrultusunda kavga vermek" manasına gelir. ${ }^{31}$

Yapılması gereken, bir karşı-iktidar oluşturmak için hiyerarşik olarak yıllarca örgütlenmek değil; tepkimizi dile getirmek, çığlı̆̆ın sesini yükseltmek, devrimin aktif unsurunu kuvvetlendirmek ve özellikle de (disiplin ve verimliliğe dayanan) iktidar mantığını reddetmektir. Peki, dünya bu şekilde değişecek mi? "Dünya iktidar olmadan nasıl değiştirilebilir? Cevabı çok açı: Bilmiyoruz.” ${ }^{32}$ diyen Holloway, mücadeleye dair umudu ${ }^{33}$ canlı tutmaktan yana geleceğe "açık" bir tavır sergiler.

Bu anarşizan Marksist eser çok eleştiriye tâbi tutulmuştur. ${ }^{34}$ Özellikle Leninist örgütlenme tarzı, sahip olduğu ortodoks sınıf mücadelesi anlayışı ve geleneksel devrim stratejilerine yönelik sıradışı fikirlerinden dolayı, sol literatürün çok ilgisini çekmiş ve eleştirilere neden olmuştur.

Fetişizm eleştirisini Marksist düşüncenin temeline yerleştiren Holloway, bu doğrultuda çalışmaya devam ederek Adorno üzerine yoğunlaşır. 2008 yllında yayınlanan Negativity and Revolution: Adorno and Political Acti$v_{\text {vism }}^{35}$ isimli yine derleme çalışmada Holloway yine merkezî sorunu etrafında tartışmaya devam eder. Reel sosyalizmin çöküşü ve Leninist devrim anlayışının işlerliğinin kaybedildiği bir anda "diyalektiğin anlamı ve onun devrimci düşüncedeki rolü” ne olacak sorusunu gündeme taşır. Athusser, Foucault, Deleuze, Derrida, Negri gibi çağdaş filozofların diyalektik materyalizmi reddetmesini, öncelikle Hegelci diyalektik materyalist sentezin, tarihi bir açıklıktan ziyade aşamalı bir senteze doğru götüren donuk yapı olarak görmesi ve diyalektiğin farkın çeşitliliğini bastırarak farkı sadece çelişkiye indirgemesi nedeniyle eleştirdiklerini kaydeder. ${ }^{36}$ Bunların karşı-

31 Holloway, İktidar Olmadan Dünyayı Değiștirmek, 149.

32 Holloway, İktidar Olmadan Dünyayı Değiștirmek, 39.

33 Bu konuda çokça Ernst Bloch'un Umut İlkesi kitabına sıklıkla referans verir. Ernst Bloch, Umut İlkesi, çev. Tanıl Bora (İstanbul: İletişim Yayınları, 2013).

34 Ayrıntılı eleştiri için bkz. Alexandros Chrysis, On the Dialectics of Power and Revolution: a Few Reflections of work of John Holloway "Change the World without Taking Power (GESİS, Leibniz-Institut für Socialwissenschaften, 2012).

35 John Holloway, Fernando Matamoros ve Sergio Tischler, Negativity \& Revolution: Adorno and Political Activism (London: Pluto Books, 2009).

36 Olumsuzluk ve Devrim: Adorno ve Politik Eylemcilik, ed. John Holloway, Fernando Matamoros ve Sergio Tischler, çev. Kutlu Tunca (İstanbul: Oto- 
na konulan fark felsefesi, Spinozacı çokluk (multitude) fikrinin diyalektik karşısında cazip görünmeye başladığına dikkat çeker. Ancak, burada Holloway ve arkadaşları diyalektiğin göz ardı edilmesini iki açıdan sakıncalı bulur. Birincisi, olumsuzlamaya dayanmayan bir fark düşüncesi liberal bir çoğulculuğa varabilme tehdidini taşır; ikincisi ise, çelişki fikrinden vazgeçilme gafletine götürebilir. Oysa sermaye, canlı eyleyişin soyut emeğe çevrildiği antagonistik bir toplumsal ilişki biçimidir. "Yararlı-yaratıcı eyleyişin muazzam ve çok renkli zenginliğini zorla soyut, değer üreten emeğe indirgeyen" ${ }^{37}$ bir şeydir sermaye.

Öyleyse teori, bizatihi sermayenin doğasında bulunan çelişkiyi göz ardı etmek ve giderek "gerçek demokrasiyi" savunmak gibi bir noktaya savrulur. Holloway'e göre, bu durumda yapılması gereken; mutlu bir senteze ulaşan, çelişkiyi mutlağın birliğinde dindiren sentetik diyalektik fikrine karşı tarihî bir aşamalar dizisi değil, bir isyan hareketi olarak görmemizi sağlayacak negatif diyalektik yaklaşımına dönmek gerekir. Negatif diyalektik için "çelişki, özdeşlik görünümü altında özdeş olmamadır, özdeşsizliğin tutarlı anlamıdır." ${ }^{38}$ Adornocu anlamda çelişkinin kavramın düşünülen şeyi tüketmediğine işaret eder. Holloway, buradan yola çıkarak, özdeşsizlik (non-identity) fikrinin tam da kendi geliştirdiği şekilde; eyleyişin soyut emeğe sığdırılamaması, eşdeğerliğin tikelliği tüketememesi, parti disiplinine sığmayan isyanın özdeşsizliği, uyumsuzluk, isyan, eleştirellik gibi tüm fikirleri için bir sağlama çıkarır: “Biz, özdeşsizliğiz. Uymayan güç, bütün özdeşleştirmelerle çelişen ve dışarı taşan güç, öznelliktir, biz’izdir. O halde biz kimiz? Biz özneyiz, herhangi bir tanıma içerilemeyiz....Özdeşlikçi bir biz değil, ayrık, uymayan, yaratıcı bir biz."39

\section{DEVRİMCİ DÖNÜŞÜMDEN ÇATLAK YARATMA STRATEJİSİNE}

İktidar Olmadan Dünyayı Değiştirmek kitabında gördüğümüz anti-kapitalist yaklaşımı eleştirel teori ile aşılayan Holloway aynı zamanda Negri ve Moretti'nin başını çektiği otonomist Marksist gelenekle de eleştirel bir ilişkiyi sürdürür. Daha önce geliştirdiği tezleri 2010 yılında yayınlanan Crack Capitalism (Kapitalizmde Çatlaklar Yaratmak) kitabı ile belirginleştirerek doktrin haline getirir.

Dîvân

$2018 / 1$

nom Yayıncılık, 2013), 11-12.

37 Olumsuzluk ve Devrim: Adorno ve Politik Eylemcilik, 15. 38 Olumsuzluk ve Devrim: Adorno ve Politik Eylemcilik, 17. 39 Olumsuzluk ve Devrim: Adorno ve Politik Eylemcilik,23. 
Dünyayı değiştirmek pratik ideasına sadık kalarak teorik gayretini sürdüren Holloway'e göre devrim ancak onu çatlaklar yaratan bir süreç olarak düşündüğümüzde düşünülebilir. Kararlılıkla vurguladığı gibi, devrim yapısal bir dönüşüm ya da devlet aygıtını ele geçirerek ulaşılan bir güç değişimi yoluyla değil, sürekli arayışlar ve yaratım süreçleri ile gelecek bir vaat olarak tasarlanmalıdır. Zira, ona göre kapitalizm tutarlı bir tahakküm sistemi değil, içerisinde çelişkiler, zayıflıklar, krizler barındıran bir sistemdir. Bu sistemin içerisindeki (sadece ekonomik olmayan) krizleri besleyerek çatlaklar bulmayı bir yöntem olarak benimser. Ona göre, "çatlak yine bir çığlık ile, isyan ya da Hayır! ile başlar, buradan bir onur (dignity), bir olumsuzlama-ve-yaratma filiz verir." ${ }^{40}$ Böylece ilgi, Leninist "iktidarı almaya yönelik araçsal hedeften, kapitalizmle uymayan toplumsal ilişkilerin yaratılması ve güçlendirilmesine kaymıştır. Onur (dignity) temel kavram halini almıştır." ${ }^{41}$ Vurguyu yine bir anti-mücadeleye yapan Holloway, analizin başlangıcına "Sermayenin mevcut durumu karşısında ezilenler ne yapmalıdır?” sorusu yerine, itaatsiz özneler nasıl sermayenin duvarlarında çatlaklar yaratabilir sorusuna odaklanır. Devrim stratejisi çatlakları yaratmak, geliştirmek ve çoğaltmak üzerine kurulmuştur. Çatlaklar mekansal (Zapasitacıların devletin giremediği alanları işgal etmesi örneğindeki gibi), zamansal (iş yavaşlatma, performans kriterlerini reddetme gibi) ya da yapısal (paraya dayalı olmayan toplumsal ilişki biçimleri kurma, formlar, konseyler, Sovyetler gibi) olabilir.

Peki çatlak nerede açığa çıkar?: Eyleyişin (doing) emeğe isyan ettiği yer ve zamanlarda. ${ }^{42}$ Kapitalizm; duvarlarını eyleyişi, soyut emeğe dönüştürerek örer. Bu duvarların krizi, çatlaması soyut emeğe dönüştürülemeyen eyleme biçimleri yaratmaktan geçer. Kitabın sorusu tam da eylemin emek biçimine sokulup öldürülmesi, birikim unsuru haline getirmesinin nasıl önüne geçilebileceği üzerine inşa olmuştur.

Holloway'in iddiası eylem ve emek arasındaki antagonizmanın Marksist gelenekte gözden kaçırıldığıdır. Oysa Marx bu ayrımdan "ekonomi politiğin berrak bir şekilde anlaşılmasındaki eksen" diye bahsetmiştir. "Ana akım Marksizm emeği pozitif bir kuvvet, umut kaynağı diye görmüş, sorunu emeğin varlığı değil, emeğin prangalanması olarak görüp zincirlerinden kurtarmaya çalışmıştır." ${ }^{43}$ Ortadoks Marksistlerin zannettiği gibi emek kutsal değildir, tam da insan eylemi emek biçiminde soyutlandığın-

40 John Holloway, Kapitalizmde Çatlaklar Yaratmak, çev. Barış Özçorlu, Bülent Doğan ve Sinem Özer (İstanbul: Otonom Yayıncılık, 2011), 25.

41 John Holloway, Kapitalizmde Çatlaklar Yaratmak, 59.

42 John Holloway, Kapitalizmde Çatlaklar Yaratmak, 103.

43 John Holloway, Kapitalizmde Çatlaklar Yaratmak, 186. 
da işçi denen karakter açığa çıkar ve sermaye üretir. Eylemin emeğe dönüştürülmesi sermayeyi üreten ve işçiyi tüketen temel manevradır. ${ }^{44}$ Yani komünist mücadele özünde emeği özgürleştirmeye değil, emeği ortadan kaldırmaya yönelmelidir. Holloway'a göre bu, eyleyişin emeğe sığmaması sayesinde olur. Eyleyiş; emeğin kalıbına sığdırılamaz, paranın soyutlama itkisinin karşısında eyleyiş reaksiyon vererek, krizler yaratır: "Eyleyiciler olarak bizler sermayenin kriziyiz öyleyse. Sınıf mücadelesi öyleyse emeğin sermayeye karşı mücadelesi değil eyleyişin emeğe karşı mücadelesi olarak anlaşılmalıdır." ${ }^{45}$ Sermaye, eylemi istihdam ve disiplin içerisinde sınırlandırmaya çalıştıkça, özdeşleştirilemeyen çatlaklar yaratmaya devam edecektir.

Demek ki sermayeye karşı mücadele öncelikle beklenmedik, potansiyel ve tekildir. Genel olarak soyut bir emeğin sermayeye karşı mücadelesi değil, an-be-an eylemleri baskılamaya çalışan sermayenin insanları tamamen kontrol altına alamamasından kaynaklanan çoklu, tikel direnişlerdir. İkincisi, bu patlayan direnişler paranın soyut özdeşliğine tâbi olmayan öznelliğin isyanıdır, bastırılmış devrimci öznenin açığa çıkışıdır. Böylelikle değeri belirleyen homojen emek zamanına karşı, yaşanan zamanın geri kazanılışı manasına gelir.

Demek ki devrim anı kapitalist üretici güçler ile üretim ilişkileri arasındaki gerilim “...kapitalist kabukla bağdaşmadıkları bir noktaya kadar ulaşır. Böylece kabuk parçalanır. Kapitalist özel mülkiyetin çanı çalmıştır. Mülksüzleştirenler, mülksüzleştirilirler." ${ }^{46}$ ifadesindeki kabuğun parçalanmasını tarihin zorunlu bir süreçle ilerlediği ve bu evreye gelene kadar emek ile sermayenin kabuk altında harmonik bir şekilde yaşadığı şeklinde anlamamak gerekir. Üretici güçler ile üretim ilişkileri arasındaki ilişki Holloway'a göre hep krizlidir, çatlaklarla doludur; kabuk çan çaldığı anda birden bire parçalanmaz, aktif mücadele, reddetme, isyan, yeni gündemler yaratma, deneyimler kazanma, sorarak yürüme gibi muhtelif aktiviteler ile duvarlar sürekli yoklanmalıdır. Devrim soyut bir plan değil, sürekli çatlaklardan ucu görülen bir umut ilkesi olarak algılanmalıdır.

44Emek güçlendikçe işçi güçsüzleşir; emek akıllandıkça işçi ahmaklaşır ve doğaya köle olur. ...Politik iktisat, iş̧̧̧iyle (emek) üretim arasındaki dolaysız ilişskiyi göz önüne almayarak, emeğin kendi içinde yatan yabancllaşmayl gizler. Emek zenginler için gerçekten çok güzel şeyler yaratır ama işçi için ürettiği yalnız yoksunluktur. Karl Marx, 1844 El Yazmaları, çev. Murat Belge (İstanbul: Birikim Yayınları, 2016), 77.

45Holloway, Kapitalizmde Çatlaklar Yaratmak, 218.

46 Karl Marx, Kapital: Ekonomi Politigin Eleştirisi, I. Cilt: Sermayenin Üretim Süreci, çev. Mehmet Selik ve Nail Satlıgan (İstanbul: Yordam Kitap, 2011), 729. 
Çatlaklar yaratma stratejisi Marksist gelenekteki üç büyük akıma bir cevap olarak tasarlanmıştır esasında. Soru şudur: zaten sermaye tarafından yaratılan işçiler, sermayeyi nasıl alaşağı edebilirler? Birinci cevap Leninist devrim görüşüdür. Buna göre işçiler gerçekten de sermaye tarafından kısıtlanmış durumdadır, kavrayışları ve bilinçleri sınırlıdır, devrimi gerçekleştirmenin tek yolu aydın bir grubun işçilerin bilincini yükselterek onlara gerçek çıkarlarının gösterilmesi, parti organizasyonu ile devleti ele geçirerek işçinin zincirlerinden kurtarılmasıdır. İkinci cevap Althusser ve Poulantzas'in yapısalcı Marksizm'leridir. Kabaca ifade edersek kapitalist toplum içerisinde sınıf ilişkileri yapısal olarak üst-belirlenmiştir (overdetermination). Devrim ancak insanların zihnine mündemiç tüm yapının değişimi ile mümkün olacak bir şeydir. Güncel üçüncü cevap ise, artık işçi sınıfının devrimci özne olmadığı, devrimin emekçilerden değil de, çok farklı marjinal kesimlerin renklerinin bir araya gelmesinden açığa çıkabileceğini düşünen anti-kapitalist hegemonya mücadelesidir. Karikatürize edersek, Lenin kapitalist kabuğun dışardan bir balyozla bir anda yıkılabileceğini, Althusser bu kabuğun ancak tüm dokusunun değişmesi ile yıkılabileceğini, anti-kapitalistler ise kabuk içindeki heterojen unsurların dengeyi bozabileceğini düşünür.

Holloway'a göre birinci cevap yetersizdir; çünkü devlet eyleyişin emeğe dönüşme uğraklarından biridir, devleti ele geçirmek eyleyişi özgürleştirmez, yeni bir iktidar mantığı üretmeye sebep olur. Althusser'e cevabı, yapısalcılığın bizi devrim fikrinden uzaklaştırdığıdır. "Yapısalcılık özneyi toplumsal ilişkilerin taşıyıcısı konumuna indirgediğinden hiçbir çıkış yolu önermez...Yapısalcılık bir Kassandra ${ }^{47}$ ideolojisidir, dünyadan ve onun kaderinden yakınsa da, yapılacak bir şey olmadığını düşünen sol entelektüelin ideolojisidir." ${ }^{48}$ Marjinal grupları harekete geçirmeye çalışan antikapitalist direnişçilere cevabı ise, sıradan insanların dışlanmasına, nüfusun büyük çoğunluğunun mücadele dışına itilmesine itirazdır. Demek ki Holloway, erken dönem yazılarında ortaya koyduğu devlet özerkliği karşıtı anti-yapısalcı yaklaşımını yapısal dönüşüm projeleri aramanın yerine koyduğu çatlaklar yaratma yöntemi ile donatır. ${ }^{49}$

47Yunan mitolojisinde geleceği görebilen ama kimseyi inandıramayan bir karakter.

48Holloway, Kapitalizmde Çatlaklar Yaratmak, 138.

$49 \mathrm{Bu}$ noktada enteresan bir şekilde yapısalcılığın en büyük rakibi olan Sartre'ın hümanist Marksizmi ile Holloway'in yolları kesişir. Her ne kadar kitaplarında Sartre'a hiç referans vermese de, kendisinin emek karşısına eylemi koyması ile Sartre'nin Critique of Dialectical Reason kitabında practico-inert yapıların karşısına eylemin özgürülüğünü koyarak ortadox Marksizm ile kavga etmesi çok benzerdir. Yine benzer bir manevrayı Han-

Dîvân

$2018 / 1$ 


\section{DEVRIMCİ ÖZNE ADAYI: ÖFKE KARDEŞLİĞİ}

$\mathrm{Bu}$ uzun girizgah ve entelektüel biyografiden sonra Öfke Günleri'nin iddialarının zeminini tartışabiliriz. Holloway, kitabın Türkçe baskısının önsözüne "Bütün dünyada bir öfke kol geziyor." ${ }^{50}$ cümlesi ile başlayarak, doğrudan Komünist Manifesto’ya gönderme yapar ve zımnen yeni bir manifesto projesine giriştiğinin işaretini verir. Atina'da Sintagma Meydanı, Wall Street Occupy Eylemleri, Şili eylemleri, Tahrir Meydanı, Gezi Parkı gibi bir dizi isyan hareketi ile bu öfkenin her yanda vücut bulduğu tespitini yapar. Dünyanın her yerinde patlak veren bu kitlesel eylemlerin ortak özelliği bir tür planlı olmayan öfke patlamaları olmalarıdır. Dünyanın tutulduğu bu öfke nöbetlerinde açığa çıkan şeyin, neoliberal iktisadi koşullarda insani yaşam koşullarından mahrum edilmiş olanların ve devlet ya da sermaye tarafından adaletsizliğe uğradığını düşünenlerin tepki vererek "Hayır!” dedikleri bir özneleşme ânı olduğunu düşünür. Ona göre, küreselleşmiş finans kapital hükümranlığında "paranın iktidarı, işsizliğin, stresin, yetersizlik duygusunun ve büyüyen eşitsizliğin iktidarıdır.” (s. 20) Öyleyse, dünya finans kapitalin imparatorluğunda birleşiyorsa, diyalektik olarak onun zıddı olan öfke de tüm dünyada yükseliyor demektir.

Tüm dünyayı düzleştirip, eşdeğer biçiminde nesneleştiren para karşısında özneleşmenin esas aracı olan öfke bizatihi ele alınacak bir kavram değildir. Holloway’a göre öfkenin hayırlı ve şerli olmak üzere iki farklı boyutu vardır. Eğer öfke, haksızlıktan ve incinmiş haysiyetten (dignity) kaynaklanıyorsa, bu öfke etrafında bir araya gelenler kendi benliklerini bırakarak "Biz" kategorisi içinde birleşirler. Holloway bu tarz öfkeyi umudun öfkesi olarak isimlendirir. Öfkenin şerli versiyonu ise gücünü hınç ve hırstan alan öfkedir; aşırı sağın ve ırkçılığın öfkesi böyle bir yıkım öfkesidir. Görüldüğü gibi, Holloway öfke üzerinden siyasal spektrumun sağ ve sol uçlarını yeniden tanımlar. Umudun öfkesi ve yıkımın öfkesi, aynı temelden, yani paranın egemenliğinden kaynaklansa da tezahürleri farklıdır. Bir yanda aşırı sağcı ve içe kapanmacı yerellikler olarak; öte yanda popülist sol, evrenselci, kollektivist dinamizmler olarak tezahür eder.

nah Arendt İnsanlık Durumu'nda emek-iş-eylem arasında yaptığı ayrımla gerçekleştirir. Bu iki örnekte de sınıf kavramının esnetilmesi, Marksist analizin bir tür eylem fenomenolojisine dönüştürüldüğü görülmekte ve burada insanlık potansiyeline dair hümanist bir umut göze çarpmaktadır. Arendt'in eylem kavramı için bkz. Siyasal Üzerine Konuşmalar, haz. Ahmet Okumuş ve Metin Demir (İstanbul: Küre Yayınları, 2016).

50John Holloway, Öfke Günleri: Paranın Hükümranlığına Karşı Öfke, çev. Utku Özmakas (Ankara: İletişim Yayınları, 2017), 7. 
Holloway'ın en dikkat çekici iddiası, öfkeyi "rasyonel bir irrasyonellik, irrasyonel dünyanın rasyonelliği” (s. 20) olarak tanımlamasıdır. Akıl ile duyguları karşıtlaştıran bir yaklaşıma karşı, siyasal bir duyguyu, militanca bir arayışı gerçek bilimsel faaliyetin temeline yerleştirir. Ona göre hakikat; akademik ve resmî söylemin sahte tarafsızlığı ile değil, partizanca bir tavır alarak araştırılabilir. Adaletsizliğin ve eşitsizliğin kol gezdiği bir dünyada itidal ve makuliyet çağrısı yapmak, soğuk kanlı akademik bir tavır sergilemek sahici bir düşünce için engeldir. Bilimselliğe yönelik bu eleştirisini Althusserci bilimselci Marksizme bir darbe ile taçlandırır: "tarihin öznesiz bir süreçmiş gibi sunulmasına karşı öfkemizi kuşanalım.” (s. 23) diye salık verir. Eleştirel teorinin pozitivizm eleştirisinde gördüğümüz önemli noktaları tekrarlayan Holloway, pozitivist bir Marksizm karşında, haysiyetini savunan değer yüklü, konumlanmış (situated), militanca bir düşünme yöntemini benimser. $\mathrm{Bu}$, onun daha önceki çalışmalarında geliştirdiği "Marks'ı özgürleştirme" (emancipating Marx) projesinin bir devamıdır. Ekonomist, yapısalcı, soğuk Marksist analizlerin karşısında, ekonomiyi göz ardı etmeyen ama Kantçı burjuva kavramları olan onur ve vicdan kavramları ile sıcak hesaplaşmaya hevesli bir rasyonel metodu savunur.

Böylelikle Holloway, çağdaş siyasal dünyanın tüm fenomenlerini öfke kavramı ile yakalamaya çalışırken, öfkenin bireysel bir irrasyonel tutku olmadığını, bilakis irrasyonel bir dünyada rasyonel bir tavır olduğunu savunur. Öfke kavramını böyle izah ettikten sonra öfkenin öznesini belirlemeye girişir.

Holloway'a göre öfkenin sabit bir öznesi yoktur. Öfke bir etkileşimden doğan bir duygulanımdır. Öyleyse odaklanılması gereken, fenomenolojik olarak öfkelenen özneye değil, öfkelendiren yapıya bakmaktır. Bu nedenle Holloway, öfke neye karşı öfkedir sorusunu sorar ve açıkça tüm dünyadaki bu öfkenin paranın saldırısına karşı bir öfke olduğu cevabını verir. "Biz sisteme karşı değiliz, sistem bize karşı" sloganına dikkat çekerek, aslında öznenin verili olmadığını, yapısal bir etkileşim sonucu bir özneleşme sürecinin doğduğunu göstermeye çalışır. Neoliberal para hareketleri sonucu kararlar ve politikalar insanların beklenti ve yaşam tarzlarını değiştirmeye başladıkça küreselleşmenin kaybedenleri olan büyük kitleler öfkenelenerek sesini yükseltmeye ve özneleşmeye başlar. Yine bir karşıtlık ikilemesinin üzerine giden yazar, devrimci bir karşı çıkış ile alışılmış yaşam koşullarını savunmaya çalışan muhafazakar tutuculuğun birlikteliğine işaret eder. Paranın saldırısı karşısında kendi yaşam koşullarını savunan; ormanıma, parkıma, üniversiteme "dokunma" diyen muhafazakar kişi aslında devrimcidir (s. 31). 
Paranın saldırısı karşısında kitleler genellikle öfkeyi kişiselleştirir, politikacılar ve uygulayıcıları sorumlu tutar. Oysa yazarın ısrarla göstermeye çalıştı̆̆ı şey, bu saldırının kişisel değil yapısal olduğudur. Politikacılar ve karar alıcılar da paranın dinamik hareketini izlemeye mahkum olan aktörlerdir; kararları şahsi ve iradi değil, yapısal ve konumsaldır. "Bu politikacıların savunucuları egemen görüşe, ne başlattıkları ne kontrol ettikleri bir toplumsal belirlenim sisteminin muazzam akışına kapılmış gidiyorlar" (s. 39). Dolayısıyla mesele politik bir mesele değildir, sorun bir iktidarın giderek yerine yenisinin getirilmesi ile çözülemez. Obama'nın değişim konusundaki başarısızlığını bu durumun açık bir örneği olarak gösterir. İktidar Olmadan Dünyayı Değiştirmek çalışmasında ayrıntılı olarak gösterdiği gibi devrim fikri iktidar ikamesi ile değil, soyut emeğin yabancılaştırmasını ortadan kaldıracak somut eylemler ile mümkün olur. Demek ki sorun aktüel siyasetin sorunu değil, neoliberal iktisadi yaklaşımlar ve onunla elbirliği yapan temsili demokrasinin iflast sorunudur. Yani, adaletsizlik ve ayrımcılığa karşı öfke konusunda daha fazla demokrasi, acil demokrasi talep etmek de yetersiz bir yaklaşımdır, zira demokratik haklar sistemi özel mülkiyete dayalı ve paranın varlığını pekiştiren bir sistem olduğu için gerçek mücadelenin zemini değildir. Gerçek mücadele nasıl olmalıdır sorusunun cevabını yine pratikten çıkarır. Sintagma'da, Tahrir'de, Puerto de Sol'de, Wall Street'de müşterek öge, politikacıların ve kurumların çözüm önerilerini reddederek sokağa inmek, konseyler, komünler ve forumlar tarzında doğrudan demokrasiyi yeniden örgütlemektir. Holloway açıkça otonomist Marksist bir pozisyon alarak paraya karşı doğrudan demokrasi pratikleri önerir: "Bir forum kurmak... ilk adım budur ama sadece ilk adım.” (s. 42)

Kitabın ilerleyen bölümlerinde paraya dair analizler yapan yazar, esasında Marx'ın Grundrisse ve Kapital'de yaptı̆̆ı bilimsel çözümlemeleri hızlı bir özet ile tekrarlar. Marx'ın Kapital'in başında yaptığı soyut emeksomut emek karşıtlığına dönerek eleştirinin özünü buraya yerleştirir. Soyut, yabancılaşmış emek; emeği ve ürünü kontrol altına alır ve öznel yaşam dünyasında zorlamalı çalışma, stres, dışlama ve yıkıma sebebiyet verir. Yerleşik kurumları disipline dayalı olarak yerinden eder; köylülüğü, üniversiteyi ve gençliği itaatkar ve güçsüz (potentia manasında) hale getirir. Holloway böylelikle eleştirisini Marx'ın gençlik yazılarında, özellikle 1844 El Yazmalari'nda ortaya koyduğu para ve soyut emeğin çözücü etkisi üzerine bina eder. Eğer sorunun kaynağı para ise, toplumsal ilişkiler para formuna girerek somut emeği dönüştürüp insanların yerleşik yaşamlarını alt üst ediyorlar ise, çözüm somut emeğe geri dönmektir. Yazar, $1844 \mathrm{El}$ Yazmaları'nda gördüğümüz naif bir hümanizmi tekrarlayarak paraya karşı durur. 
Tam bu noktada Holloway'in neden klasik Marksist bir yaklaşımla sermayeye değil de paraya karşı olduğu anlaşllabilir. Genç Marx'ta da esas teorik mücadele soyut/yabancılaşmış emek ve paranın çözdüğü toplumsal ilişkilerdir. Oysa olgun Marx para ile kendi başına mücadele etmeyi bırakıp, kapitalist üretim biçiminde paranın hakikati olan sermaye ile uğraşır. Kapitalist üretim biçiminde para sermaye olarak varlığını sürdürür. Toplumsal ilişkileri çözücü parayla kavga etmek ile sermayeyle kavga etmek arasında sıradan bir terimsel fark yoktur. Holloway, Marx'ın sermaye birikimin kategorik buyruğunu formüle ettiği "Biriktiriniz, Biriktiriniz! İşte, Musa da bu, peygamberler de bu." ${ }^{51}$ cümlesini “boyun eğ, boyun eğ, sahibine ve efendine itaat et, Paranın Mantığına itaat et!” şeklinde dönüştürerek, eleştirinin odağını bilimsel olarak saptanan artık değer sömürüsü üzerine değil de, somut emek ve insanca yaşam üzerinde bina olan tahakküme kaydırır. Ona göre sorunun nedeni “insanlığımız"dır. "Hayır!” dediğimiz noktada, boyun eğmediğimiz noktada paranın nesneleştirici mantığı çözülmeye başlayacak, semptomu gördüğümüz anda o kendiliğinden dağllacaktır. Küresel finans kapitalin sömürüsünü fabrikanın dışına taşınması borç ve kredi baskısı ile tüm sosyal katmanları ve politikayı tahakküm altına alınmasına sebep olmuştur. ${ }^{52}$ Baskılanan sadece emeğimiz değil, tüm insanlığımızdır; öyleyse çözüm de insan haysiyetinin öfke ile yeniden ayağa kaldırılmasıdır.

\section{ÖFKENİN ÖZNELERİNE DAİR TEREDDÜTLER}

Holloway'in etkileyici ve umut verici söylevini izlemek heyecan verici olmakla birlikte onun projesinin bir çok soruyu cevapsız bıraktığı, hatta bu cevapsızlığı bir fazilet olarak gördüğü ileri sürülebilir. Öncelikle en temel sorun şudur: Paranın egemenliğine karşı özneleşen, haysiyet kavramı dolasıyla öfkelenip bir aidiyete ittiba eden bu "Biz" neyi dışlamaktadır? Bugün dünyanın en büyük sermayedarları kapitalizmden şikayet ederken, kapitalizmden muzdarip olan herkes "Biz"e nasıl dahil edilebilir? Diyalektik, böylesi cılız tanımlanmış bir aidiyet ile antagonist mücadeleye nasıl girişilebilir? Daha terminolojik ifadesi ile aynı üretim koşulları altında sömürülen kendinde sınıfin nesnel koşulları olmadan kendisi-için-sınıfnasıl

51 Karl Marx, Kapital: Ekonomi Politigin Eleştirisi, I. Cilt: Sermayenin Üretim Süreci, çev. Mehmet Selik ve Nail Satlıgan (İstanbul: Yordam Kitap, 2011).

52 Ayrıntılı analizleri için bkz. Werner Bonefeld ve John Holloway, Küreselleşme Çağında Para ve Sinıf Mücadelesi (İstanbul: Otonom Yayıncılık, 2007), 13-35. 
var olabilir ${ }^{53}$ Kapitalizmden şikayetçi uluslararası bir caz sanatçısı ile kapitalist üretim koşulları altında ezilen domates eken köylü nasıl ortak bir gelecek inşa edebilir sorusu bir muamma olarak durmaktadır.

İkinci sorun, kapitalizm karşısında feryadın devrimsel bir güce sahip olduğunu düşünecek olursak, kapitalizmin, ilkel birikiminden beri milyonları feryat ettirmiş olmasına rağmen daha da güçlendiği olgusal bir gerçekse, feryadın kendisi otomatik olarak nasıl pozitif yaratıcı eyleme büyülü bir şekilde dönebilir? Kapitalizm tarihi savaşlar, felaketler, yıkımlar ile doludur, ancak bu felaketler sermaye birikimini durdurmamış; aksine, kapitalizmin, çaresiz insanları ucuz işgücü olarak kullanmasına neden olmuştur. XVI. yüzyıl Britanya'sında topraklarından edilen köylülerin kitlesel sefaleti, XIX. yüzyıl sömürgeciliğinin vahşeti, XX. yüzyıldaki görülmemiş kitlesel savaşların yıkımı insanlık onurunu ayaklar altına alan felaketler olmasına rağmen, sebep olduğu çığlıkların hepsi kaybolup gitmiştir.

Üçüncü sorun, emek sürecinin disiplin altında kısıtlanması karşısında eyleyişin belirsizliği, yaratıcılığı ve heterojenliğine vurgu yaparak, emek karşısında eyleyişi yücelten Holloway, verdiği örneklerde hep görmek istediği eylemlerden (pasta yapmak, dans etmek, konsey kurmak) bahseder. Oysa kapitalizmin emek dayatmasına karşı terör örgütleri ve aşırı tutucu cemaatler de bir araya gelebilmektedir. Eylemi kendi başına pozitif bir şey olarak mı alacağız, yoksa eylemler için iyi kötü bir tasnif sistemini tekrar kurarak onu yeniden mi sınıflandıracağız? Günümüzde aşırı sağ ve radikal selefi hareketler kapitalizme ve Batı'nın sömürgeciliğine karşı öfke kardeşliğini devreye sokmaya çalışırken, bu tarz hareketlerle koalisyon mu yapmak gerekir, yoksa bunlar eyleşi donduruyor diye karşı durmak mı? Böyleyse öfke kardeşliği kategorik olarak kimlerle ittifak yapacak sorunu belirsizliğini korumaktadır.

Bunun devamında gelecek bir başka soru ise din ile ilişki sorunudur. Badiou ve Zizek gibi post-sovyet dönemi Marksistleri din ile bir şekilde eleştirel irtibatı sürdürürken, Holloway koca külliyatında dinden nedereyse hiç bahsetmez. Din olgusuna dikkat edilmemesini sadece bir konunun atlanması olarak görmemek gerekir. Bu eksiklik Marksist gelenek içerisinde uzun süre tartışmaya vesile olan mesiyanizm sorununa kör kalınmasına neden olur. Holloway dini hiç dikkate almazken kendisi önemli ölçüde

53 Ekonomik şartlar, ilkin memleket halkını emekçiler haline getirmişti. Sermayenin egemenliği, bu yığına böylece ortak bir durum, ortak çıkarlar yaratmış bulunuyor. Bu yığın böylece şimdiden, sermaye karşısında, bir sınıftır. Fakat henüz kendisi için değil. Karl Marks, Felsefenin Sefaleti: M. Proudhon'un Sefaletin Felsefesi'ne Cevap, çev. Ahmet Kardam (Ankara: Sol Yayınları, 2011), 172. 
kurtuluş teolojisi diline düçar olur. Marksist devlet formasyonu analizinden yola çıkan Holloway'in apokaliptik bir mesiyanizm söylemine vardığı söylenebilir.

Bununla bağlantılı ve belki en önemli sorun, paranın hükümranlığı aşırı derece militarize savaş makinaları ile müdaafa ediliyorken, bunun karşısına çıkmaya talip olan öfkelilerin sadece sivil itaatsizlik mi göstereceklerine dair belirsizliktir. "Hayır!" diyen özneler sadece çığlık atarak mı karşılık verecekler, yoksa varlıklarını korumak adına karşı bir kuvvet mi oluşturacaklar? Eğer böyle bir yapılanmaya girilecekse bu durumda tekrar bir devletsi meşru şiddet aygıtlarına geri dönme ihtiyacı hasıl olmayacak mı? Eğer silahsız bir sivil itaatsizlik bekleniyorsa, öfkenin öznelerini, çıkarları tehdit edildiğinde kan dökmekten hiç çekinmeyen paranın iktidarının altında yok olmaktan ne koruyacaktır? Holloway kendi pozisyonunu reel sosyalizmin çöküşü üzerinden temellendirmekte ve bizi müştereklere, forumlara çağırmaktadır. Oysa bu yöntemler de -en dramatik örneği Paris Komünü olan- defalarca denenmiş ve başarısız olmuş girişimlerdir.

Bir diğer mesele, Holloway'in neoliberal kapitalizmin eleştirisini yine neoliberal zihniyet kalıpları içerisinde yapmasıdır. David Harvey neoliberalizmi bir tür zaman-mekan sıkışması olarak tanımlar. Yani, piyasa sözleşmelerinin coğrafi alanı ne kadar büyük (küresel), süresi ne kadar kısa ise o kadar iyidir. ${ }^{54}$ Küresel neoliberal paranın egemenliğine karşı küresel bir öfkeyi çıkaran Holloway, uzun dönemli sömürüler sonucu teşekkül eden sınıf aidiyetinden ziyade anlık ortaklaşmalar üzerine dayanan sözleşmeler ittifakını cazip bulur. Paranın egemenliğinin ürettiği neoliberal yönetişim (govermentality) düzenine, bu düzenin dışında kaldığı varsayılan "insanlık," "onur," "haysiyet” gibi liberal değerler ile direnebilme kapasitesi yetersiz görünmektedir.

Holloway yapısalcılığın belirlenimleri karşısında özgürlükçü, açık bir Marksizmin imkanını araştırırken adım adım voluntarizme doğru kaymakta; "biz" istemediğimiz, öyle düşünmediğimiz takdirde kapitalist üretim ilişkileri dağılacak gibi düşünmektedir. Oysa sermayenin yarattığı nesnel dünyanın fetiş karakteri biz öyle düşünmesek bile karşımıza dikilmektedir. Para ve mübadele ilişkileri insanın ikincil doğası olmuştur. Anlık çatlaklar yaratmak suretiyle bu yerleşik doğanın nasıl değişebileceği sorunu da cevapsız kalır. Marx'ın Alman filozoflara yaptığı istihzai eleştiri burada oldukça ufuk açıcıdır:

"Bir zamanlar, gözü kara bir adam, insanların suda boğulmalarının tek nedeninin, onların yerçekimi fikrine saplanmaları olduğunu savunuyordu. Eğer insanlar, örneğin, bunun bir hurafe olduğunu ilan edip bu fikri kafala- 
rından çıkarıp atsalarmış, suda boğulma tehlikesinden tamamen kurtulmuş olacaklarmış. Ömrü boyunca, istatistiklerin kendisine sayısız kanıt sunarak zararlı sonuçlarını tekrar tekrar ortaya koyduğu bu yerçekimi yanılgısına karşı savaştı. Bu gözü kara adam, Almanya'daki yeni devrimci filozofların prototipiydi." ${ }^{55}$

İddiamız odur ki, Holloway yeni bir Komunist Manifesto yazmaya kalkarken anarşist, voluntarist tavrıyla yeni bir Sefaletin Felsefesi üretmiştir. Her ne kadar sefaletteki devrimci yanı görmemek, toplumun diyalektik doğasını gözden kaçırmak, parayı üretim ilişkilerinden soyutlamak gibi Proudhon'un yaptığı hatalara düşmese de, onunla aynı iradecilik, ümitvar naiflik ve haysiyet gibi burjuva katogorilerini kullanmak konusunda benzeşir. İkisi de "bir işçi olarak insanı değil de bir insan olarak işçiyi”"56 önceleyerek hümanist bir voluntarizmi yeniden üretirler.

55 Karl Marks-Frederich Engels, Alman İdeolojisi, 2. bas, çev. Tonguç Ok \& Olcay Geridönmez (İstanbul: Evrensel Basım Yayın, 2013), 23-24. 56 Marks, Felsefenin Sefaleti, 62. 


\section{KAYNAKÇA}

Alexandros, Chrysis. On the Dialectics of Power and Revolution: a few reflection of work of John Holloway "Change the World without Taking Power." GESİS, Leibniz-Institut für Socialwissenschaften, 2012.

Bloch, Ernst. Umut İlkesi cilt 1, 3. bas. Çev. Tanıl Bora. İstanbul: İletişim Yayınları, 2013.

Dardor Pierre \& Laval Chiristian. Dünyanın Yeni Akll: Neoliberal Toplum Üzerine Deneme. Çev. Işık Ergüden. İstanbul: Bilgi Üniversitesi Yayınları, 2012

Demir, Metin \& Okumuş Ahmet, ed. Siyasal Üzerine Konuşmalar. İstanbul: Küre Yayınları, 2016.

Fülberth, George. Kapitalizmin Kısa Tarihi. Çev. Sadık Usta. İstanbul: Yordam Yayınları, 2010.

Grubacic, Andrej. “Neden Holloway.” Kapitalizmin İçinde, Kapitalizme Karşı ve Kapitalizmin Ötesinde: San Francisco Dersleri, 9-23. Ankara: İletişim Yayınları, 2016, .

Harvey, David. Neoliberalizmin Kısa Tarihi. Çev. Aylin Onacak. İstanbul: Sel Yayıncılık, 2015.

Hegel, G. W. F. Hukuk Felsefesinin Prensipleri ya da Ana Hatlarda Doğal Hak ve Devlet Bilimi. Çev. Cenap Karakaya. İstanbul: Sosyal Yayınları, 1991.

Holloway, John. Change the World without Taking Power. London: Pluto Press, 2002.

Holloway, John. İktidar Olmadan Dünyayı Değisstirmek, 4. bas. Çev. Pelin Siral. Ankara: İletişim Yayıncılık, 2015.

Holloway, John. Kapitalizmde Çatlaklar Yaratmak. Çev. Barış Özçorlu, Bülent Doğan \& Sinem Özer. İstanbul: Otonom Yayıncılık, 2011.

—. Kapitalizmin içinde, Kapitalizme Karşı, Kapitalizmin Ötesinde: San Francisco Dersleri. Çev. Utku Özmakas. Ankara: İletişim Yayınları, 2016.

—. Öfke Günleri: Paranın Hükümranlığına Karşı Öfke. Çev. Utku Özmakas, Ankara: İletişim Yayınları, 2017.

— \& Sol Picciotto, ed. State and Capital: A Marxist Debate. Austin: University of Texas Press, 1979.

— \& Bonefeld Werner, ed. Post-Fordism and Social Form: A Marksist Debate on Post-Fordist State. London, Palgrave Macmillan, 1991.

_ \& Bonefeld Werner, ed. Global Capital, National State, and the Politics of Money. London: Palgrave Macmillan, 1995.

— - Gunn, Richard \& Bonefeld Werner, ed. Open Marxism vol III: Emancipating Marx. London: Pluto Press, 1995. 
— \& Bonefeld Werner. Küreselleşme Çağında Para ve Sınıf Mücadelesi. Çev. Serkan Mercan. İstanbul: Otonom Yayıncılık, 2007.

—, Matamoros Fernando ve Sergio Tischler, ed. Negativity \& Revolution: Adorno and Political Activism. London: Pluto Books, 2009.

—-, Matamoros Fernando ve Sergio Tischler, ed., Olumsuzluk ve Devrim: Adorno ve Politik Eylemcilik. Çev. Kutlu Tunca. İstanbul: Otonom Yayıncılık, 2013.

Karatani, Kojin. Transkritik: Kant ve Marks Üzerine. Çev. Erkan Ünal. İstanbul: Metis Yayınları, 2008.

Kant, Immanuel. Ahlak Metafiziğinin Temellendirilmesi. Ankara: Türkiye Felsefe Kurumu Yayınları, 2009.

Marx, Karl. 1844 El Yazmalarl, 10. bas. Çev. Murat Belge. Ankara: Birikim Yayınları, 2016.

—. Kapital: Ekonomi Politigin Eleştirisi, I. Cilt: Sermayenin Üretim Süreci. Çev. Mehmet Selik ve Nail Satlıgan. İstanbul: Yordam Kitap, 2011.

—. Felsefenin Sefaleti: M. Proudhon'un Sefaletin Felsefesi'ne Cevap, 7. bas. Çev. Ahmet Kardam. Ankara: Sol Yayınları, 2011.

— Geridönmez. İstanbul: Evrensel Basım Yayın, 2013.

— kara: Sol Yayınları, 1976.

Miliband Ralph, Poulantzas Nicos ve Laclau Ernesto. Kapitalist Devlet Sorunu. Çev. Yasemin Berkman. Ankara: İletişim Yayınları, 1990.

Sartre, J. Paul. Critique of Dialectical Reason vol 1. Çev. Alan Sheridan-Smith. London: Verso Publishing, 2006. 